\title{
INTERNATIONAL LEGAL PROVIDING FOR ENVIRONMENTAL PROTECTION IN SETTLEMENTS
}

\author{
A.M. RADCHENKO, PhD (Law), \\ assistant of Department of the Agricultural, Land and Environmental Law \\ to the name of academician V.Z.Yanchuk, \\ National University of Life and Environmental Sciences of Ukraine \\ E-mail: simpoti@meta.ua \\ O.M. TKACHENKO,
}

graduate student of Department of the Agricultural, Land and Environmental Law

to the name of academician V.Z.Yanchuk,

National University of Life and Environmental Sciences of Ukraine

E-mail: sandroaa6060@gmail.com

\begin{abstract}
Summary. The article examines the basic rules of international legal acts regulating the issues of environmental protection in settlements. The experience of international legal regulation of environmental protection of settlements has been studied, which showed that this issue is currently regulated in the following areas: 1) international legal documents, which establish general requirements for the implementation of the principle of sustainable development and its environmental component in all countries; 2) international legal documents, which establish special requirements for sustainable development of settlements, taking into account their environmental component; 3) international legal documents, which set requirements for environmental protection. It is established that at the beginning of the XXI century. it became clear that only the international integration of efforts - economic, political and institutional, creates the preconditions for preventing a global environmental catastrophe. Settlements are recognized as one of the largest sources of environmental pollution and climate change on the planet.
\end{abstract}

Keywords: settlement, environment, legal protection, ecology, environment

\section{Introduction.}

The history of the twentieth century is associated with the significant development of international legal cooperation between states in various fields. Among the priorities of cooperation of states at the international level it is expedient to determine the consolidation and provi- sion of international legal regulation of environmental protection in settlements. Because an important task of modern environmental legislation is the protection of the environment in cities, towns and rural settlements. The legal status, role and importance of cities and other settlements require the creation of the most favorable conditions for life and health, 
work and leisure. That's why, today there is a need to study international legal acts in the field of environmental protection in settlements.

\section{Analysis of recent researches and publications.}

General theoretical and practical issues of international legal regulation of environmental protection in settlements were partially in the center of attention of both domestic and foreign scientists, such as: V. Andreytsev, O. Gafurova, M. Deinega, V. Ermolenko, Yu. Krasnova, N. Kobetska, N. Malysheva, T. Makarova, Yu. Shemshuchenko and others.

The purpose is a study of the main international legal acts regulating the issues of environmental protection in settlements.

\section{Results.}

The concept of protection and restoration of the human environment as one of the main goals of social progress and development was first put forward in UN Security Council Resolution 2542 (XXIV) of December 11, 1969 in the «Declaration of Social Progress and Development».

In previous years, the improvement of living conditions was associated by the world community with the growth of industrial production, which required measures to overcome the negative effects of urbanization and industrialization.

This theme was further developed in the Stockholm Declaration of the United Nations Conference on the Environment on June 16, 1972, which emphasized that it is human who is primarily responsible for the state of the environment, and the protection and improvement of environment were proclaimed the most important goal for the humanity. The paper identifies 26 principles of activity regulation, among which rational use of resources, reduction of impacts on ecosystems, planning of settlements and urbanization, etc.

Since today there is a large number of international legal acts governing the environmental protection of settlements, we propose to classify them in the following areas: 1) international legal documents, which establish general requirements for the implementation of the principle of sustainable development and its environmental component by all countries of the world; 2) international legal documents, which establish special requirements for sustainable development of settlements, taking into account their environmental component; 3) international legal documents, which set requirements for environmental protection.

In the first place among the thise documents are the UN Declarations for human settlements: Vancouver Declaration (Principles) on Human Settlements, adopted at the UN Conference on Human Settlements (Habitat I) in Vancouver (Canada) in 1976; Istanbul Declaration on Human Settlements, adopted at the UN Special Conference on Human Settlements (Habitat II) in Istanbul (Turkey) on June 3-14, 1996; The Declaration on Cities and Other Settlements in the New Millennium, adopted by Resolution S-25/2 of the 25th Special Session of the UN General Assembly on 9 June 2001, and the new Urban Development Program adopted by the United Nations Conference on Housing and Sustainable Urban Development (Habitat III), held in Quito, Ecuador, from 17 to 20 October 2016 (Mark J. McDonnell, 2011: 1).

In view of the provisions of the Declaration and Program of Action for the Establishment of a New International 
Economic Order, the Charter of Economic Rights and Duties of States, from 31 May to 11 June 1976 in Vancouver (Canada) was held the First Conference of United Nations about Human Settlements (Habitat I) as a result of which the Vancouver Declaration on Human Settlements was adopted.

The Declaration expressed concern about the increase in the world's population, uncontrolled urbanization and declining quality of life.

Paragraph 11 stated that «all actions taken by countries and peoples should be based on deep respect for the protection of environmental resources», the main element of which in settlements is land. It was proclaimed that human settlements policy should be based on the application of progressive minimum standards of acceptable quality of life, accounting local characteristics and combating excessive consumption.

Following the Vancouver Conference in December 1977, the UN General Assembly adopted a resolution establishing a Commission on Human Settlements. The main task of the Commission was to promote the development of international cooperation on human settlements, housing and civil engineering and building materials. In March 1978, the Secretariat and Executive Body of the United Nations Commission on Human Settlements (United Nations Center for Human Settlements - Habitat) was established.

Continuing the development of the principles and provisions of the Vancouver Declaration was the Istanbul Declaration of the United Nations Conference on Human Settlements (Habitat II), 3-14 June 1996, in which the Heads of State and Government, official delegations of the countries which were gathered at the Conference, in order to preserve the global environment and improve the quality of life in settlements, declared their commitment to sustainable structures of production, consumption, transport and development of settlements; prevention of environmental pollution; abidance with the intensity of ecosystem use; preserving opportunities for future generations.

The next important document was the Declaration on Cities and Other Settlements in the New Millennium, adopted by Resolution S-25/2 of the Special Session of the UN General Assembly of June 9, $2001 \ll 5+$ Istanbul».

On 12 December 2001, the 56th session of the UN General Assembly adopted a resolution (A / RES / 56/206) on raising the status of the United Nations Center for Human Settlements (Habitat) to the level of a full-fledged the United Nations Human Settlements Programme (UN-Habitat). The Governing Body of the Program was the Human Settlements Commission, has been transformed into the Board of Governors of the United Nations Human Settlements Program and has become a subsidiary body of the General Assembly.

The new urban development program was adopted at the United Nations Conference on Housing and Sustainable Urban Development (Habitat III), held in Quito (Ecuador) from 17 to 20 October 2016 and approved at the 68th plenary session meeting of the United Nations General Assembly on December 23, 2016.

This Program of urban development is a shared vision of a more sustainable future, in which everyone has equal rights and access to the benefits and opportunities provided by cities, and in which to achieve this sustainable future the international community rethinks urban systems and the physical shape of urban space (Saunders, 2000: 2). 
The next block of sources is the international acts of regional character in the field of local self-government, among which it is necessary to allocate: the European declaration of the rights of cities of 1992 and the European charters of cities of March 18, 1992 and dated May 29, 2008; The Charter of the Cities of Europe on the Road to Sustainable Development (Aalborg Charter), endorsed by the European Conference on the Sustainable Development of Europe's Large and Small Cities in Aalborg (Denmark) on 27 May 1994; Leipzig Charter on Sustainable Development of European Cities 2007 etc.

One of the main places in a number of international European documents is the European Declaration of the Rights of Cities, adopted by the Standing Conference of Local and Regional Authorities of Europe in 1992.

This Declaration establishes the rights of citizens of European cities, including the right to protect the territory from pollution, in connection with which cities must manage natural and energy resources; local authorities must protect nature and greenery; nature protection should be a factor in increasing the participation of city residents in their lives and the pride of the city.

The first European Charter of Cities was adopted by the Congress of Local and Regional Authorities of the Council of Europe in 1992. It was a key step in the necessary recognition of the role of cities. However, given the rapid economic development, environmental crises and other changes in modern Europe 16 years after the adoption of the first European Charter of Cities the Congress of Local and Regional Authorities of the Council of Europe in May 2008 in Strasbourg adopted the European Urban Charter II - Manifesto of New Urban- ism. Its preamble states that during this crucial period, cities became the part of European territory most affected by globalization, as cities became the main place for Europe to adapt to the new technological, environmental, economic and social conditions that emerged as a result of globalization.

The Charter is based on the fact that citizens have fundamental rights in cities, including the right to protection from the polluted environment, repeating the provisions of the previous Declaration. In addition, the Charter clearly stipulates that these rights belong to all urban residents, regardless of gender, age, origin, race, religion, socio-economic and political status, physical and psychological disabilities. Thus, the Charter states that one of the responsibilities of local authorities is to protect these rights by developing an appropriate strategy.

At the same time, the Ministers of the Environment of Western, Eastern Europe, the United States and the Newly Independent States in Conference «Environment for Europe» at the 1993 Conference in Lucerne (Switzerland) adopted the «Environmental Action Program for Central and Eastern Europe». The program is based on the principle of direct inclusion of environmental aspects in the processes of economic reform. Particular attention is paid to environmental issues at the local level, which have been identified as a priority. This program outlines a multi-stage process for national governments to set environmental priorities and implement measures to prevent environmental pollution and conserve natural resources in order to improve the environmental situation at the local level. Due to the decentralization of power since 1993, the national governments of many Central European countries have delegated 
a wide range of environmental responsibilities to local governments. As a result, local authorities are responsible for water supply and sewerage, heat supply, waste collection and recycling, green care, and land use planning. In addition, new mechanisms and instruments of environmental policy at the level of local self-government have been introduced, such as local environmental programs.

European experience has shown that the procedure for developing local environmental programs should be regulated by local authorities.

The new focus on environmental issues is the recognition that local authorities and citizens have the best understanding of their own problems, difficulties and needs, so decentralizing the decision-making process allows them to adapt the necessary environmental measures to them. Communities around the world, including Central Europe, are gradually embracing a new way of thinking about one's own future and the effectiveness of influencing it. They are extremely interested in new approaches to their development and at the same time seek to preserve the environment, reduce the burden of poverty and disease, improve the quality of life and create a strong and viable local economy. In response to these aspirations, the concept of sustainable local development emerged, which included the task of strengthening the community's economy, taking into account the ability of the natural environment to function properly and support human life. According to the International Council for Local Environmental Initiatives (ICLEI), sustainable local development provides basic ecological, social and economic living conditions for all residents of the community, without endangering the viability of natural, man-made and social system.
Therefore, local environmental policy should be clearly articulated, unambiguous, concise, written in a language understandable and accessible to a wide range of people, to have free access to the public. It is developed for the long term, should be realistic and practically implemented, as well as define the boundaries of environmental goals and objectives of the community or municipality. It is important that the commitments contained in environmental policy are realistic, achievable, and that they contribute to the development of the environmental management system. The decisions that are made in the process of its development are fundamentally important for the community or municipality and take into account the strategic priorities of their development. Therefore, in addition to the working group, it is recommended to involve representatives of the top management of the local self-government body in the development of the draft policy.

At the Inspiring Prospects - Aalborg +10 conference in 2004, the Aalborg Commitments were presented, stating that commitments are accepted as a resource by which signatories can choose priorities that are appropriate to the local situation and their I need; a joint local process is initiated to define specific goals and time frames to track progress towards achieving them. The cities that signed the Aalborg Charter have acknowledged their commitment to implementing the principles of sustainable development. The Aalborg Commitments have made it possible to move from principles to objectives relating to the 10 main areas of activity, including environmental commitments, including: 1) reducing primary energy consumption and increasing the distribution of renewable and clean energy, improving water quality and efficiency of its use, to promote the idea of 
biodiversity conservation, to take care of existing natural objects and green spaces, to improve the quality of lands, to preserve ecologically productive lands, to improve air quality; 2) reduce the amount of waste generated and increase their reuse and recycling, manage waste in accordance with existing standards of best practice, avoid unreasonable energy consumption, increase energy end-use efficiency, guarantee sustainable supply, actively promote sustainable production and consumption; 3 ) reduce the impact of transport on the environment.

About the reduction of harmful effects of environmental on human health and hygiene is mentioned in a number of European declarations on health in cities, in particular: Athens Declaration for Healthy Cities, adopted at the International Conference on Healthy Cities, initiated by the World Organization health care in Athens in June 1998; Belfast Charter for Healthy Cities: «Local Action Force», adopted on 22 October 2003; Zagreb Healthy Cities Declaration: «Health and equality issues in health should be reflected in all local strategies», 2008, etc.

Following the adoption of the EU's Climate and Energy Initiative Package in 2008, the European Commission launched the Covenant of Mayors to encourage and support the efforts of local authorities to develop and implement sustainable energy development policies. The Covenant of Mayors is a flagship initiative launched by the European Union that involves local and regional authorities that make voluntary commitments to increase energy efficiency and increase the use of renewable energy sources in their territories. By adhering to these commitments, the signatories of the Agreement seek to reduce their own CO2 emissions by at least $20 \%$ by 2020 , thus contributing to the development of an environmentally friendly economy and improving the quality of life.

\section{Conclusions and prospects.}

Therefore, from all the above we can conclude that the largest block of sources in this area should be considered international acts on environmental protection. A review of official UN documents dating to the twentieth century shows that the gradual expansion of ideas about causation in the ecosphere led at the turn of the 1960s and 1970s to the identification of three main groups of interrelated problems - economic, social and environmental. Awareness of the main reasons for the increase in these problems ended with the formation of a new paradigm for all mankind, which was defined as «sustainable development». The methodology of sustainable development was mainly formed before the early 90 's of XX century, after which came the stage of active practical implementation of the idea. At the beginning of the XXI century. it became clear that only the international integration of efforts - economic, political and institutional, creates the preconditions for preventing a global environmental catastrophe. Settlements are recognized as one of the largest sources of environmental pollution and climate change on the planet.

\section{References}

1. McDonnell, Mark J. (2011). The History of Urban Ecology: An Ecologist's Perspective. Urban Ecology: Patterns, Processes and Applications. Available at: https://www. researchgate.net/publication/285216178_ The_History_of_Urban_Ecology_-_An_ Ecologist's_Perspective (in English).

2. Saunders, Peter (2000). Urban ecology. In: Paddison, Ronan (ed.) Handbook of Urban Studies. Uban Geography - Urban Planning. SAGE, London, 36-51 (in English). 


\section{А.М. РадчеНКО \& О.М. ТКवчеНКО (2020). МІЖНАРОДНО-ПРАВОВЕ ЗАБЕЗПЕЧЕННЯ ОХОРОНИ НАВКОЛИШНЬОГО СЕРЕДОВИЩА В НАСЕЛЕНИХ ПУНКТАХ. ПрवВО.}

Людина. Довкілля, 11(4): 53-59. https://doi.org/10.31548/law2020.04.006.

Анотація. У статті досліджено основні норми міжнародно-правових актів, що регулюють питання охорони навколишнього середовища в населених пунктах. Вивчено досвід міжнародно-правового регулювання охорони довкілля населених пунктів, який показав, що че питання сьогодні регулюється за такими напрямами: 1) міжнародноправові документи, якими встановлюються загальні вимоги щодо реалізації принципу сталого розвитку та його екологічної складової всіма країнами світу; 2) міжнародноправові документи, якими встановлюються спеціальні вимоги щодо сталого розвитку населених пунктів, враховуючи їх екологічну складову; 3) міжнародно-правові документи, якими встановлені вимоги щодо охорони навколищнього середовища. Встановлено, що на початку XXI cm. стало очевидно, що тільки міжнародна інтеграція зусиль-економічних, політичних та інституційних, створює передумови запобігання глобальній екологічній катастрофі. Населені пункти визнані одним з найбільших джерел забруднення довкілля та зміни клімату на планеті.

Ключові слова: населений пункт, довкілля, правова охорона, екологія, навколишнє середовище 